\title{
ANALISIS TINGKAT KEPUASAN PASIEN TERHADAP PENANGANAN TERAPI OKUPASI DI INSTALASI REHABILITASI MEDIK RSUP PROF. DR. R. D. KANDOU MANADO
}

\author{
${ }^{1}$ Meilany D. Wongkar \\ ${ }^{2}$ Joudy Gessal \\ ${ }^{2}$ Leonard S. Angliadi
}

\author{
${ }^{1}$ Kandidat Skripsi Fakultas Kedokteran Universitas Sam Ratulangi Manado \\ ${ }^{2}$ Bagian Ilmu Kedokteran Fisik dan Rehabilitasi Universitas Sam Ratulangi Manado \\ Email: mwongkar11_226@yahoo.co.id
}

\begin{abstract}
Medical rehabilitation aims to lessen the impact of a disability and enhance the ability of people with disabilities, therefore, they can be involved in social interaction. One of the rehabilitation treatments is occupation therapy which helps individuals by giving suggestions and enhancing independence. Quality is a dynamic condition which fills or surpass the expectations. Quality is closely related to costumers' satisfaction. It encourages the costumers to create a strong bond of relationship. This study aimed to obtain patients' satisfaction degree toward the implementation of occupation therapy in the Medical Rehabilitation Installation Prof. Dr. R. D Kandou Hospital, Manado. This was a descriptive observational study. Sampleds were collected by using purposive sampling. The result of the T Test analysis showed that there was a significant difference between before and after the therapy with a p value $=0.000$. Based on the result of the satisfaction degree to the variable of expectation and reality, the average obatined was 7.9. Conclusion: Patients' expectation degree was higher than the reality of service that they received.
\end{abstract}

Keywords: medical rehabilitation, occupation therapy, patients satisfaction degree.

\begin{abstract}
Abstrak: Rehabilitasi medik bertujuan untuk mengurangi dampak keadaan cacat dan meningkatkan kemampuan penyandang cacat sampai interaksi sosial. Salah satu pelayanan rehabilitasi ialah terapi okupasi, yang membantu individu dalam memberi anjuran dan menjamin bantuan untuk meningkatkan kemandirian. Kualitas merupakan kondisi dinamis yang memenuhi atau melebihi harapan. Kualitas memiliki hubungan yang sangat erat dengan kepuasan pelanggan, yaitu kualitas memberikan suatu dorongan kepada pelanggan untuk menjalani ikatan hubungan yang kuat. Penelitian ini bertujuan untuk mengetahui gambaran tingkat kepuasan pasien terapi okupasi di Instalasi Rehabilitas Medik RSUP. Prof. Dr. R. D. Kandou. Penelitian ini bersifat deskriptif observasional. Pengambilan sampel dilakukan secara purposive sampling. Hasil analisis uji t menunjukkan terdapat perbedaan bermakna sebelum dan sesudah terapi dengan nilai $\mathrm{p}=0,000$. Berdasarkan hasil uji nilai tingkat kepuasan terhadap variabel harapan dan kenyataan menunjukkan perbedaan dengan nilai rata-rata 7,9. Simpulan: Nilai harapan pasien lebih besar dari kenyataan pelayanan yang mereka terima.

Kata kunci: rehabilitasi medik, terapi okupasi, tingkat kepuasan pasien
\end{abstract}

Rumah Sakit merupakan salah satu lembaga yang bergerak dibidang pelayanan jasa kesehatan dengan tanggungjawab memberikan pengobatan, memberikan perawatan, mengusahakan kesembuhan dan kesehatan pasien, serta mengupayakan pendidikan hidup sehat bagi masyarakat. Menurut Menteri Kesehatan Republik Indonesia Nomor 340/MENKES/PER/III/2010, rumah sakit 
adalah institusi pelayanan kesehatan yang menyelenggarakan pelayanan kesehatan perorangan secara paripurna yang menyediakan pelayanan rawat inap, rawat jalan, dan gawat darurat. Hakikat dasar dari rumah sakit adalah pemenuhan kebutuhan dan tuntutan pasien yang mengharapkan penyelesaian masalah kesehatannya pada rumah sakit.Pasien memandang bahwa hanya rumah sakit yang mampu memberikan pelayanan medis sebagai upaya penyembuhan dan pemulihan atas rasa sakit yang dideritanya. Pasien mengharapkan pelayanan yang siap, cepat tanggap dan nyaman terhadap keluhan penyakit pasien. ${ }^{1}$

Program rehabilitas adalah bentuk pelayanan kesehatan yang terpadu dengan pendekatan medik, psikososial, edukasional-vokasional yang bertujuan mencapai kemampuan fungsional semaksimal mungkin dan mencegah serangan berulang. Dalam pelayanan rehabilitasi ini merupakan pelayanan dengan pendekatan multidisiplin yang terdiri dari dokter ahli rehabilitasi medik, perawat, fisioterapis, terapi okupasional, pekerja sosial medik, psikolog serta klien dan keluarga turut berperan. ${ }^{2}$ Menurut WHO, semua tindakan yang ditunjukan guna mengurangi dampak keadaan cacat dan meningkatkan kemampuan penyandang cacat sampai interaksi sosial disebut dengan rehabilitas medik, dan program ini sangat diperlukan guna meringankan kecacatan pada cacat primer dan pencegahan terhadap keadaan cacat berat. $^{3}$

Salah satu pelayanan rehabilitasi adalah terapi okupasi.Terapi okupasi merupakan sumber yang membantu individu dalam memberi anjuran dan menjamin bantuan untuk meningkatkan kemandirian. Pasien dilatih untuk berpindah dan melakukan aktivitas seharihari. $^{4}$ Prinsip-prinsip terapi okupasi terbagi dua yaitu berdasarkan kegunaan dan berdasarkan pelaksanaanya. Melalui terapi okupasi diharapkan dapat memperbaiki fungsi fisik, intelektual, sosial dan emosi individu sebagaimana mestinya. $^{5}$

Pada bulan Agustus-Desember 2013 jumlah pasien di Instalasi Rehabilitasi Medik RSUP Prof.Dr.R.D Kandou sebanyak 3194 pasien, dengan perincian sebagai berikut; sebanyak 542 pasien pada bulan Agustus, 649 pasien pada bulan September, 761 pasien pada bulan Oktober, 768 pasien pada bulan November, 474 pasien pada bulan Desember.

Kualitas pelayanan kesehatan terhadap masyarakat sangat tergantung kepada pemberi layanan dan sistem yang dipakai. Dokter, perawat, dan tenaga penunjang medis serta non medis yang bertugas dirumah sakit harus memahami cara melayani konsumennya dengan baik. ${ }^{6}$ Dalam setiap tindakan medis setiap pasien sangat mengharapkan adanya patient safety, karena patient safety juga merupakan salah satu pengukur akan tingkat kepuasan dari pasien.

Berdasarkan hal-hal di atas penulis merasa perlu untuk melakukan penelitian ini untuk menilai tingkat kepuasan pasien di Instalasi Rehabilitas Medik BLU RSUP.Prof. Dr. R. D. Kandou dengan menggunakan kuisioner untuk menilai tingkat kepuasan pasien terhadap terapi okupasi. Diharapkan penelitian ini dapat memberikan informasi tentang bagaimana pelayanan di rehabilitas medik guna memenuhi kebutuhan pasien.

\section{METODE PENELITIAN}

Penelitian ini adalah metode penelitian deskriptif observasional. Penelitian ini akan dilaksanakan di Instalasi Rehabilitasi Medik RSUP Prof. Dr. R. D. Kandou Manado. Waktu penelitian dilaksanakan pada bulan November 2014 -Januari 2015.

Populasi target dalam penelitian ini ialah pasien yang sedang melakukan terapi okupasi di Instalasi Rehabilitasi Medik. Pengambilan sampel dilakukan secara purposive sampling yakni penarikan sampel kepada seluruh responden yang dianggap memenuhi 
kriteria untuk memberikan data secara objektif dan akurat.

Kriteria inklusi yaitu pasien yang bersedia dan berpartisipasi untuk ikut dalam penelitian, pasien yang sedang melakukan terapi okupasi minimal $>$ 2minggu dan pasien yang kooperatif. Kriteria eksklusi yaitu pasien yang tidak bersedia berpartisipasi untuk ikut dalam penelitian. Variabel dalam penelitian ini yaitu karakteristik responden yang terdiri dari umur jenis kelamin, pekerjaan, diagnosis penyakit, lama terapi, terapi penyerta dan variabel kepuasan pasien yang terdiri dari kondisi lingkungan fisik, hubungan interpersonal dan pelayanan terapi.

Cara pengambilan data dilakukan observasi langsung dengan cara menggunakan kuisioner yang telah berisi pertanyaan-pertanyaan yang mendukung bagi peneliti untuk mengumpulkan data

\section{HASIL PENELITIAN DAN BAHASAN}

Lokasi penelitian bertempat di Instalasi Rehabilitasi Medik RSUP Prof. Dr. R.D Kandou Manado. Subjek penelitian yaitu pasien dewasa yang kooperatif dan sudah lebih dari atau 2 minggu terapi okupasi. Jumlah responden dalam penelitian ini berjumlah 32 orang. Pengumpulan data dilakukan dengan observasi langsung menggunakan kuisioner. Gambaran responden yang menjadi sampel diklasifikasikan berdasarkan jenis kelamin, umur, pekerjaan, diagnosis, lama terapi, terapi penyerta dan anggota tubuh yang terganggu.

Hubungan terapi okupasi terhadap tingkat kepuasan pasien, dimana nilai $r=$ 0,031 dan nilai $\mathrm{p}=0,866$. Berdasarkan nilai $\mathrm{r}$ dapat diketahui bahwa kekuatan hubungannya antara dua variabel sangat lemah, sedangkan berdasarkan nilai $\mathrm{p}=$ $0,866>0,05$, yang menyatakan tidak terdapat hubungan antara terapi okupasi dengan tingkat kepuasan pasien (Tabel 1).
Tabel 1. Hubungan Terapi Okupasi dengan Tingkat Kepuasan Pasien

\begin{tabular}{cc}
\hline & Tingkat \\
& Kepuasan \\
\hline Terapi & $\mathrm{r}=0,031$ \\
\cline { 2 - 2 } Okupasi & $\mathrm{p}=0,866$ \\
\hline
\end{tabular}

Hubungan diagnosis dengan kenyataan dalam pelayanan di rumah sakit, dimana nilai $\mathrm{r}=-0,045$ dan nilai $\mathrm{p}=$ 0,805 . Berdasarkan nilai $r$ dapat diketahui bahwa kekuatan hubungannya antara dua variabel sangat lemah, sedangkan berdasarkan nilai $\mathrm{p}=0,805>0,05$, yang menyatakan tidak terdapat hubungan antara diagnosis dengan kenyataan dalam pelayanan di rumah sakit.

Tabel 2. Hubungan Diagnosis dengan Kenyataan Kepuasan Pasien

\begin{tabular}{cc}
\hline & $\begin{array}{c}\text { Kenyataan Pelayanan } \\
\text { RS }\end{array}$ \\
\hline \multirow{2}{*}{ Diagnosis } & $\mathrm{r}=-0,045$ \\
\cline { 2 - 2 } & $\mathrm{p}=0,805$ \\
\hline
\end{tabular}

Hubungan lama terapi dengan kenyataan dalam pelayanan di rumah sakit, dimana nilai $\mathrm{r}=0,042$ dan nilai $\mathrm{p}=$ 0,821 . Berdasarkan nilai $r$ dapat diketahui bahwa kekuatan hubungannya antara dua variabel sangat lemah, sedangkan berdasarkan nilai $\mathrm{p}=0,821>0,05$, yang menyatakan tidak terdapat hubungan antara lama terapi dengan kenyataan dalam pelayanan di rumah sakit (Tabel 3).

Tabel 3. Hubungan Lama Terapi dengan Kenyataan Kepuasan Pasien

\begin{tabular}{cc}
\hline & Kenyataan Pelayanan RS \\
\hline \multirow{2}{*}{ Lama Terapi } & $\mathrm{r}=0,042$ \\
\cline { 2 - 2 } & $\mathrm{p}=0,821$ \\
\hline
\end{tabular}

Hubungan terapi penyerta dengan kenyataan dalam pelayanan di rumah sakit, dimana nilai $\mathrm{r}=-0,030$ dan nilai $\mathrm{p}=$ 0,870. Berdasarkan nilai $\mathrm{r}$ dapat diketahui bahwa kekuatan hubungannya antara dua variabel sangat lemah, sedangkan berdasarkan nilai $\mathrm{p}=0,870>0,05$, yang 
Wongkar, Gessal, Angliadi: Analisis tingkat kepuasan...

menyatakan tidak terdapat hubungan antara lama terapi dengan kenyataan dalam pelayanan di rumah sakit (Tabel 4).

Tabel 4. Hubungan Terapi Penyerta dengan Kenyataan Kepuasan Pasien

\begin{tabular}{cc}
\hline & \multicolumn{2}{c}{ Kenyataan Pelayanan RS } \\
\hline \multirow{2}{*}{ Terapi Penyerta } & $\mathrm{r}=-0,030$ \\
\cline { 2 - 2 } & $\mathrm{p}=0,870$ \\
\hline
\end{tabular}

Hubungan diagnosis dengan kenyataan dalam pelayanan di rumah sakit, dimana nilai $\mathrm{r}=0,017$ dan nilai $\mathrm{p}=$ 0,926. Berdasarkan nilai $r$ dapat diketahui bahwa kekuatan hubungannya antara dua variabel sangat lemah, sedangkan berdasarkan nilai $\mathrm{p}=0,926>0,05$, yang menyatakan tidak terdapat hubungan antara anggota gerak yang terganggu dengan kenyataan dalam pelayanan di rumah sakit (Tabel 5).

Tabel 5. Hubungan Anggota Gerak Terganggu dengan Kenyataan Kepuasan Pasien

\begin{tabular}{cc}
\hline & $\begin{array}{c}\text { Kenyataan } \\
\text { Pelayanan RS }\end{array}$ \\
\hline $\begin{array}{c}\text { Anggota Gerak } \\
\text { Terganggu }\end{array}$ & $\mathrm{r}=0,017$ \\
\cline { 2 - 2 } & $\mathrm{p}=0,926$ \\
\hline
\end{tabular}

Terdapat kemajuan sebelum terapi dan setelahterapi diperoleh $\mathrm{p}=0,000<$ 0,05, yang menyatakan bahwa terdapat perbedaan terapi okupasi sebelum dan setelah terapi okupasi dengan nilai ratarata 59,18 (Tabel 6).

Tabel 6. Analisis Uji T Nilai Terapi Okupasi

\begin{tabular}{ccc}
\hline & Mean & Kemajuan \\
\hline $\begin{array}{c}\text { Terapi } \\
\text { Okupasi }\end{array}$ & 59,18 & $\begin{array}{c}\mathrm{t}=21,521 \\
\mathrm{p}=0,000\end{array}$ \\
\hline
\end{tabular}

Nilai signifikan terhadap variabel kenyataan dan harapan diperoleh $\mathrm{p}=$ $0,000<0,05$, yang menyatakan bahwa terdapat perbedaan tingkat kepuasan antara kenyataan dan harapan dengan nilai ratarata 7,9 (Tabel 7).
Tabel 7. Analisis Uji $\mathrm{T}$ Nilai Tingkat Kepuasan

\begin{tabular}{ccc}
\hline & Mean & $\begin{array}{c}\text { Harapan - } \\
\text { Kenyataan }\end{array}$ \\
\hline $\begin{array}{c}\text { Tingkat } \\
\text { Kepuasan }\end{array}$ & 7,9 & $\begin{array}{c}\mathrm{t}=4,035 \\
\mathrm{p}=0,000\end{array}$ \\
\hline
\end{tabular}

Nilai signifikan terhadap variabel kenyataan dan harapan diperoleh $\mathrm{p}=$ $0,000<0,05$, yang menyatakan bahwa terdapat perbedaan tingkat kepuasan tangibles antara kenyataan dan harapan dengan nilai rata-rata 2,5 (Tabel 8).

Tabel 8. Analisis Uji $\mathrm{T}$ Nilai Tingkat Kepuasan Tangibles

\begin{tabular}{ccc}
\hline & Mean & $\begin{array}{c}\text { Harapan }- \\
\text { Kenyataan }\end{array}$ \\
\hline $\begin{array}{c}\text { Tingkat } \\
\text { Kepuasan }\end{array}$ & 2,5 & $\begin{array}{c}\mathrm{t}=1,439 \\
\mathrm{p}=0,000\end{array}$ \\
\hline
\end{tabular}

Nilai signifikan terhadap variabel kenyataan dan harapan diperoleh $\mathrm{p}=$ $0,566>0,05$, yang menyatakan bahwa tidak terdapat perbedaan tingkat kepuasan antara kenyataan dan harapan dengan nilai rata-rata 0,4 (Tabel 9).

Tabel 9. Analisis Uji $\mathrm{T}$ Nilai Tingkat Kepuasan Empati

\begin{tabular}{ccc}
\hline & Mean & $\begin{array}{c}\text { Harapan - } \\
\text { Kenyataan }\end{array}$ \\
\hline $\begin{array}{c}\text { Tingkat } \\
\text { Kepuasan }\end{array}$ & 0,4 & $\begin{array}{c}\mathrm{t}=1,179 \\
\mathrm{p}=0,566\end{array}$ \\
\hline
\end{tabular}

Nilai signifikan terhadap variabel kenyataan dan harapan diperoleh $\mathrm{p}=$ $0,000<0,05$, yang menyatakan bahwa terdapat perbedaan tingkat kepuasan antara kenyataan dan harapan dengan nilai rata-rata 2,3 (Tabel 10).

Tabel 10. Analisis Uji $\mathrm{T}$ Nilai Tingkat Kepuasan Reliability

\begin{tabular}{ccc}
\hline & Mean & $\begin{array}{c}\text { Harapan - } \\
\text { Kenyataan }\end{array}$ \\
\hline $\begin{array}{c}\text { Tingkat } \\
\text { Kepuasan }\end{array}$ & 2,3 & $\begin{array}{c}\mathrm{t}=1,208 \\
\mathrm{p}=0,000\end{array}$ \\
\hline
\end{tabular}


Nilai signifikan terhadap variabel kenyataan dan harapan diperoleh $\mathrm{p}=$ $0,006<0,05$, yang menyatakan bahwa terdapat perbedaan tingkat kepuasan antara kenyataan dan harapan dengan nilai rata-rata 1,5 (Tabel 11).

Tabel 11. Analisis Uji $\mathrm{T}$ Nilai Tingkat Kepuasan Ketanggapan

\begin{tabular}{ccc}
\hline & Mean & $\begin{array}{c}\text { Harapan - } \\
\text { Kenyataan }\end{array}$ \\
\hline $\begin{array}{c}\text { Tingkat } \\
\text { Kepuasan }\end{array}$ & 1,5 & $\begin{array}{c}\mathrm{t}=0,459 \\
\mathrm{p}=0,006\end{array}$ \\
\hline
\end{tabular}

Menyatakan bahwa terdapat perbedaan tingkat kepuasan antara kenyataan dan harapan dengan nilai ratarata 1,1 (Tabel 12).

Tabel 12. Analisis Uji $\mathrm{T}$ Nilai Tingkat Kepuasan Kepastian

\begin{tabular}{ccc}
\hline & Mean & $\begin{array}{c}\text { Harapan - } \\
\text { Kenyataan }\end{array}$ \\
\hline $\begin{array}{c}\text { Tingkat } \\
\text { Kepuasan }\end{array}$ & 1,1 & $\begin{array}{c}\mathrm{t}=0,359 \\
\mathrm{p}=0,005\end{array}$ \\
\hline
\end{tabular}

Data dari hasil analisis uji $t$ menunjukan bahwa terdapat perbedaan yang bermakna sebelum dan sesudah terapi dengan diperoleh $\mathrm{p}=0,000$. Kemajuan terhadap penangan terapi okupasi ini dengan nilai rata-rata 59,18. Ditunjang dari frekuensi lamanya terapi atau ketaatan terapi serta terapi penyerta yang dijalani menunjukan ada kemajuan terapi. Peralatan yang menunjang dan penangan yang baik juga akan memberikan dampak pada kemajuan terapi. Sebagai okupasi terapis perlu berempati, senyum, ramah dan juga menghibur pasien sebagai dukungan untuk kesembuhannya. ${ }^{23}$

Dimensi kualitas pelayanan sangat berperan dalam kepuasan pasien, yang terdiri dari tangible, reliabilitas, responsif atau ketanggapan, asuransi atau jaminan dan empati. ${ }^{22}$ Perlu dinilai tingkat kepuasan pasien berdasarkan kenyataan pelayanan yang mereka dapatkan dibandingkan dengan tingkat harapan pasien.

Dimensi tangible dilihat dari bagaimana ruang terapinya, ruang tunggu cukup atau tidak, tempat terapi nyaman atau tidak, adanya peralatan yang lengkap atau menunjang dalam proses terapi, ketersediaan toilet serta penampilan yang rapi dari terapis okupasi. Berdasarkan hasil uji nilai tingkat kepuasan dilihat dari dimensi tangible menunjukan terdapat perbedaan antara harapan dan kenyataan pelayanan pasien dengan nilai rata-rata 2,5 .

Dimensi yang selanjutnya yaitu empati yang dilihat dari waktu pelayanan cukup atau tidak, pelayanannya sesuai kebutuhan pasien, sikap sopan dan ramah dari terapis okupasi serta mendengarkan keluhan pasien. Berdasarkan hasil uji menunjukan nilai $\mathrm{p}=0,566$ dimana tidak terdapat pebedaan antara kenyataan dan harapan. Ini berarti empati dari terapis okupasi telah sesuai dengan harapan pasien sehingga menunjukkan kepuasan pasien dalam dimensi empati.

Dimensi reliability/ keandalan dinilai dari bagaimana pelayanan terapi yang diberikan berhati-hati atau tidak, terapis okupasi menjelaskan penyakit yang diderita pasien, selain itu menjelaskan terapi yang akan diberikan atau tindakan yang akan dilakukan. Berdasarkan hasil uji dengan nilai $\mathrm{p}=0,000$ menunjukan terdapat perbedaan antara kenyataan dan harapan pasien pada dimensi ini.

Pada dimensi responsive/ ketanggapan dinilai bagaimana terapis okupasi tanggap dalam melayani pasien, melayani dengan baik, tepat, cepat dan melakukan tindakan sesuai dengan prosedur. Berdasarkan hasil uji dengan nilai $\mathrm{p}=0,006$ menunjukkan terdapat perbedaan antara harapan dan kenyataan pasien terhadap ketanggapan terapis okupasi.

Dimensi yang terakhir yaitu assurance/ kepastian dimana dilihat kemampuan dan pengetahuan terapis okupasi dalam diagnosis pasien atau dalam menentukan terapi yang dibutuhkan pasien, terapis okupasi mampu menjawab 
pertanyaan pasien seputar penyakit atau terapi yang pasien jalani secara meyakinkan sehingga pasien akan merasa aman dan nyaman dengan pelayanan yang diberikan. Berdasarkan hasil uji didapatkan nilai $\mathrm{p}=0,005$ menunjukkan terdapat perbedaan antara kenyataan dan harapan pada dimensi ini.

Berdasarkan hasil uji nilai tingkat kepuasan terhadap variabel harapan dan kenyataan menunjukan perbedaan dengan nilai $\mathrm{p}=0,000$ dan nilai rata-rata 7,9 dimana nilai harapan tidak sesuai dengan kenyataan. Hasil ini menunjukkan bahwa nilai harapan pasien lebih besar dari kenyataan pelayanan yang mereka terima. Pasien mengharapkan kualitas pelayanan yang lebih baik. Namun demikian, dari segi empati pelayanan yang diberikan sudah memuaskan karena sesuai nilai harapan pasien.

\section{DAFTAR PUSTAKA}

1. Mulyadi D, Fadli U, Ningsih S. Analisis Manajemen Mutu Pelayanan Kesehatan Pada Rumah Sakit Karawang. 2013 [3 April 2013]. Available from

http://jurnal.feunsika.ac.id/wpcontent/ uploads/2013/06/AnalisisManajemenMutu-Pelayanan-Kesehatan PadaRumah-Sakit-Islam-Karawang.pdf.

2. Purwanti O, Maliya A. Rehabilitas Klien Pasca Stroke. 2008. Available from:http://publikasiilmiah.ums.ac.id/ bitstream/handle/123456789/471/1h.p df?sequence $=1$.

3. Hamid T, Satori D. Ilmu Kedokteran Fisik dan Rehabilitasi. Surabaya: Unit Rehabilitas Medik RSUD. Dr. Soetomo; 1992.

4. Muttaqin A. Buku Ajar Asuhan Keperawatan Klien Dengan Gangguan Sistem Pernapasan. Jakarta: Salemba Medika, 2008; p. 383.

5. Nurlina. Terapi Okupasi Untuk Keterampilan Pita Rambut Pada Anak Tuna Grahita. 2008. Available from : http://ejournal.unesa.ac.id/article/7526 /83/article.pdf.

6. T. M. Perilaku Organisasi, Jakarta: Raja Grafindo Persada, 2002.
7. Wahyuni K, Tulaar A. Kedokteran Fisik dan Rehabilitasi. Jakarta: PERDOSRI, 2012; p. 7.

8. Ibrahim AS. Stroke. Medika. 2001;XVIII.

9. Soetjiningsih. Tumbuh Kembang Anak, Bali. Jakarta: Buku Kedokteran EGC, 1995; p. 181.

10.Widati S. Rehabilitasi. Available from: http://file.upi.edu/Direktori/FIP/JUR. PEND._LUAR_BIASA/19531014198 7032-

SRI_WIDATI/MK_REHAB/REHAB ILITASI_PSIKO_FISIKAL.pdf

11.Sugiamin M. Rehabilitasi Psikofisikal, Bandung. 2007. Available from: http://file.upi.edu/Direktori/FIP/JUR._ PEND._LUAR_BIASA/19540527198 7031-

MOHAMAD_SUGIARMIN/REHAB ILITASI_PSIKOFISIKA1.pdf

12.Wahyuni K, Tulaar A. Kedokteran Fisik dan Rehabilitasi. Jakarta: PERDOSRI, 2012; p. 7-8.

13.Riyadi S, PurwantoT. Asuhan Keperawatan Jiwa. Yogyakarta: Graha Ilmu, 2009.

14. World Health Organization. International classification of functioning, disability and health (ICF). 2007. Available from:http://who.int/classificatioin/icf/ site/icftemplate.cfm?myurl=home

15.Yerxa EJ. The social and psychological experience of having a disability: Implications for occupational therapists. London, 2001.

16.King JC, Nelson TR, Heye ML, Turtorro TC, Titus MND. Prescription, referrals, order writing and the rehabilitation team function. In: DeLisa JA, Gans BM. Rehabilitation Medicine: Principles and Practice. Philadelphia: LippincottRaven Publishers, 1998.

17.Barnes JG. Secrets of Customer Relationship Management. Yogyakarta, 2003

18.Kotler P. Manajemen Pemasaran: Analisis, Perencanaan, Implementasi dan Pengendalian. Jakarta: Salemba Empat, 2000.

19.Utomo S. Memahami Fenomena Kepuasan Pasien Rumah Sakit. Jurnal Manajemen Kesehatan. 2009.

20.Tjiptono F. Strategi Pemasaran, Yogyakarta. 2000. Available from: 
Jurnal e-Clinic (eCl), Volume 3, Nomor 2, Mei-Agustus 2015

http://eprints.uns.ac.id/4677/1/138651 008201007591.pdf.

21.Nova R. Pengaruh Kualitas Pelayanan Terhadap Kepuasan Pasien, Surakarta. 2010 Available from: http://eprints.uns.ac.id/4677/1/138651 008201007591.pdf.

22.Supranto J. Pengukuran Tingkat Kepuasan Pelanggan untuk Menangkap Pangsa Pasar. Jakarta: Rineka Cipta, 2006
23. Yuliastuti, Arso S, Nugraha P. Hubungan Antara Persepsi Kualitas Pelayanan Dengan Minat Kunjungan Ulang Pasien Rawat Jalan Okupasi Terapi RS Ortopedi dr. R. Soeharso Surakarta. 2010. Available from: http://www.academia.edu/3063884/H ubungan_Antara_Persepsi_Kualitas_P elayanan_Dengan_Minat_Kunjungan _Ulang_Pasien_Rawat_Jalan_Okupas i_Terapi_RS_Ortopedi_dr._R._Soehar so_Surakarta_ 